\title{
Article \\ Osteogenic Potential of Magnesium (Mg)-Doped Multicomponent Bioactive Glass: In Vitro and In Vivo Animal Studies
}

\author{
Saeid Kargozar ${ }^{1, *}$, Peiman Brouki Milan ${ }^{2,3, * \mathbb{D}}$, Moein Amoupour ${ }^{4}$, Farzad Kermani ${ }^{5}$, Sara Gorgani ${ }^{1}$, \\ Simin Nazarnezhad ${ }^{1}$ (D), Sara Hooshmand ${ }^{6}(\mathbb{D})$ and Francesco Baino ${ }^{7, *(\mathbb{D})}$
}

check for

updates

Citation: Kargozar, S.; Milan, P.B.; Amoupour, M.; Kermani, F.; Gorgani, S.; Nazarnezhad, S.; Hooshmand, S.; Baino, F. Osteogenic Potential of Magnesium (Mg)-Doped Multicomponent Bioactive Glass: In Vitro and In Vivo Animal Studies. Materials 2022, 15, 318. https:// doi.org/10.3390/ma15010318

Academic Editor: Roman Perez Antoñanzas

Received: 2 December 2021 Accepted: 23 December 2021 Published: 3 January 2022

Publisher's Note: MDPI stays neutral with regard to jurisdictional claims in published maps and institutional affiliations.

Copyright: (C) 2022 by the authors. Licensee MDPI, Basel, Switzerland. This article is an open access article distributed under the terms and conditions of the Creative Commons Attribution (CC BY) license (https:// creativecommons.org/licenses/by/ $4.0 /)$.
1 Tissue Engineering Research Group (TERG), Department of Anatomy and Cell Biology, School of Medicine, Mashhad University of Medical Sciences, Mashhad 917794-8564, Iran; sara.gorgani70n@gmail.com (S.G.); smn.nazarnezhad@yahoo.com (S.N.)

2 Cellular and Molecular Research Centre, Iran University of Medical Sciences, Tehran 144961-4535, Iran

3 Department of Tissue Engineering and Regenerative Medicine, Faculty of Advanced Technologies in Medicine, Iran University of Medical Sciences, Tehran 144961-4535, Iran

4 Department of Medical Biotechnology, Faculty of Allied Medicine, Iran University of Medical Sciences, Tehran 144961-4535, Iran; moein.amoupour@gmail.com

5 Department of Materials Engineering, Faculty of Engineering, Ferdowsi University of Mashhad (FUM), Azadi Sq., Mashhad 917794-8564, Iran; farzadkermani73@gmail.com

6 Nanotechnology Research and Application Center (SUNUM), Sabanci University, Istanbul 34956, Turkey; sara.houshmand@sabanciuniv.edu

7 Department of Applied Science and Technology (DISAT), Institute of Materials Physics and Engineering, Politecnico di Torino, 10129 Torino, Italy

* Correspondence: kargozarsaeid@gmail.com (S.K.); peiman.brouki@gmail.com (P.B.M.); francesco.baino@polito.it (F.B.)

\begin{abstract}
The use of bioactive glasses (BGs) has been quite fruitful in hard tissue engineering due to the capability of these materials to bond to living bone. In this work, a melt-derived magnesium (Mg)doped BG (composition: $45 \mathrm{SiO}_{2}-3 \mathrm{P}_{2} \mathrm{O}_{5}-26 \mathrm{CaO}-15 \mathrm{Na}_{2} \mathrm{O}-7 \mathrm{MgO}-4 \mathrm{~K}_{2} \mathrm{O}(\mathrm{mol} . \%)$ ) was synthesized for being used in bone reconstruction. The prepared BGs were then manufactured as three-dimensional (3D) scaffolds by using the sponge replica approach. The microstructure of the samples was assessed by X-ray diffraction (XRD) and the surface morphology was observed by using scanning electron microscopy (SEM). The in vitro bioactivity and the release of osteo-stimulatory $\mathrm{Mg}^{2+}$ ions from the prepared samples were investigated over 7 days of incubation in simulated body fluids (SBF) In vitro cellular analyses revealed the compatibility of the $\mathrm{Mg}$-doped BGs with human osteosarcoma cells (MG-63 cell line). Moreover, the Mg-doped BGs could induce bone nodule formation in vitro and improve the migratory ability of human umbilical vein endothelial cells (HUVECs). In vivo osteogenic capacity was further evaluated by implanting the BG-derived scaffolds into surgicallycreated critical-size bone defects in rats. Histological and immunohistological observations revealed an appropriate bone regeneration in the animals receiving the glass-based scaffolds after 12 weeks of surgery. In conclusion, our study indicates the effectiveness of the Mg-doped BGs in stimulating osteogenesis in both in vitro and in vivo conditions.
\end{abstract}

Keywords: bioactive glasses; scaffold; magnesium; ion release; osteogenesis; bone tissue engineering

\section{Introduction}

Exploring efficient strategies for treating bone lesions has gained increasing significance in recent years due to the worldwide raise in accidental injuries, obesity, congenital genetic abnormalities, and, more importantly, the aging population [1]. In this regard, the use of transplant materials (e.g., autografts, allografts, and xenografts) has been quite promising; however, several limitations are associated to their extensive usage in the clinic, including the shortage of donors, the risk of immune rejection, and the possibility of 
zoonoses (disease or infection transmissible from vertebrate animals to humans) when xenografts are used [2]. In order to overcome these barriers, researchers have accomplished successful tissue engineering platforms to fabricate and optimize bone substitutes in the lab towards the clinic [3,4]. Synthetic biomaterials have revealed some important benefits including high reproducibility, easy and unlimited availability, as well as their stable quality, which make them better candidates compared to natural biomaterials [4]. Bioactive glasses (BGs) as a subclass of synthetic bone alternatives have attained great attention in regenerative medicine due to their constructive characteristics in inducing angiogenesis and osteogenesis [5-8]. Furthermore, the granule/particulate form of these BGs is the most clinically applicable form, which simply fits the defect anatomy due to some advantages including a high surface-to-volume ratio, the ease of handling, and potent hemostatic properties [9]. Bioactive scaffolds, used as a proper environment with a porous temporary supporting structure for the 3D growth of cells/tissues, are commonly available and capable of integrating with bone tissue in order to improve bone regeneration [10]. These properties make scaffolds highly promising bone substitutes with optimized porosity and satisfying mechanical stability in inducing bone regeneration through facilitating cell migration and attachment in a comparable rate to that of natural new bone formation [11].

Designing BG scaffolds with novel compositions has continuously progressed to finely tune and optimize their biological and physico-chemical properties. The incorporation of small amounts of therapeutic metal ions into the bioactive scaffold structure has become the most attractive strategy to reach the maximum medical efficiency of the platform [12,13]. Magnesium (Mg), as an alkaline intracellular earth metal with the total content of about $24 \mathrm{~g}$ (1 mole) per $70 \mathrm{~kg}$ in an adult body mainly located in bones and other soft tissues (e.g., muscles), can be used in the treatment of osteoporosis and bone repair since it is capable of reducing fracture risk and increasing bone density through inhibiting the osteoclast functions as well as promoting the osteoblast activities [14,15]. Furthermore, because $1.11 \mathrm{wt} \%$ of dentin and $0.47 \mathrm{wt} \%$ of bones consists of $\mathrm{Mg}^{2+}$ ions, it plays an essential role in different biological and biochemical processes in the human body including cytoskeletal integrity via the synthesis of proteins and nucleic acids, regulating active calcium transport, and activating phagocytosis as well as skeletal tissue development and bone remodeling [16,17].

Thereby, the addition of $\mathrm{Mg}$ to BGs has been thought of great importance due to its biocompatibility and applicability in the human body for targeted therapy as well as its key role in bone tissue development; furthermore, $\mathrm{MgO}$ can modify and adjust the mechanical, thermal, and physical properties of such silicate-based platforms. In order to improve available treatment strategies, this study focuses on the development of $\mathrm{Mg}$-doped melt-derived BG scaffolds that were implanted in rats to evaluate their bone regenerative potential.

\section{Materials and Methods}

\subsection{Glass Synthesis and Scaffold Fabrication}

The glass $\left(45 \mathrm{SiO}_{2}-3 \mathrm{P}_{2} \mathrm{O}_{5}-26 \mathrm{CaO}-15 \mathrm{Na}_{2} \mathrm{O}-7 \mathrm{MgO}-4 \mathrm{~K}_{2} \mathrm{O}\right.$ mol.\%) was produced by melting and quenching in cold water, as described elsewhere [18]. Briefly, the glass precursors (high-purity powders of $\mathrm{SiO}_{2}, \mathrm{Ca}_{3}\left(\mathrm{PO}_{4}\right)_{2}, \mathrm{CaCO}_{3},\left(\mathrm{MgCO}_{3}\right)_{4} \cdot \mathrm{Mg}(\mathrm{OH})_{2} \cdot 5 \mathrm{H}_{2} \mathrm{O}$, $\mathrm{Na}_{2} \mathrm{CO}_{3}$, and $\mathrm{K}_{2} \mathrm{CO}_{3}$, all purchased from Sigma-Aldrich (Saint-Louis, MO, USA) were carefully weighed by using an analytical balance, homogeneously mixed and heated to $1500{ }^{\circ} \mathrm{C}$ (heating rate: $12{ }^{\circ} \mathrm{C} / \mathrm{min}$ ) in a platinum crucible inside an electrically-heated furnace (Nabertherm 1800, Nabertherm GmbH, Lilienthal, Germany). The melt was cast into cold deionized water to obtain a "frit". The "frit" was pulverized by ball milling, and the glass particles were finally sieved below $32 \mu \mathrm{m}$ for further analysis and processing.

BG-derived scaffolds with a trabecular-like 3D architecture mimicking that of cancellous bone were produced by polymer sponge replication [19]. Sacrificial porous polyurethane cuboids $(10 \mathrm{~mm} \times 10 \mathrm{~mm} \times 10 \mathrm{~mm})$ were obtained from a panel of open-cell polyurethane (45 ppi) by using a scalpel and soaked in a water-based glass slurry so that the glass particles 
could coat the foam struts and surface, as described elsewhere [20]. After being dried for $6 \mathrm{~h}$ in air, the samples underwent a thermal treatment $\left(950{ }^{\circ} \mathrm{C}\right.$ for $3 \mathrm{~h}$ inside a Nabertherm Muffle Furnace 1300 L9/11/SKM/P330 (Nabertherm GmbH, Lilienthal, Germany); heating rate: $5{ }^{\circ} \mathrm{C} / \mathrm{min}$ ) to obtain sintered scaffolds replicating the pore/strut architecture of the porous polymeric template.

\subsection{Characterizations}

\subsubsection{Bioactivity Assessment in Simulated Body Fluid (SBF)}

In order to clarify the bioactivity potential of Mg-doped BGs, a simulated body fluid (SBF) was prepared according to the method described by Kokubo and Takadama [21]. In brief, $150 \mathrm{mg}$ of glass powder was immersed in $100 \mathrm{~mL}$ of SBF and incubated at $37^{\circ} \mathrm{C}$ in an orbital shaker (KS 4000i control, IKA, Staufen city, Germany) at a constant agitation of $200 \mathrm{rpm}$ for 1,3, and 7 days. At each time point, the glass powders were collected and rinsed with acetone (Merck, Darmstadt, Germany) to halt any further reaction. The formation of a hydroxyapatite layer on the BG surface was analyzed by using X-ray diffraction (XRD) technique, and the morphology was studied with field-emission scanning electron microscopy (FESEM) (MIRA3, TESCAN, CZ).

\subsubsection{Crystallization Degree Analysis by XRD}

The phase composition of the materials produced was determined by X-ray diffraction (XRD) (Explorer GNR, Novara, Italy) before and after incubation in SBF. For this aim, the synthesized samples were introduced to an X-ray powder diffractometer equipped with a monochromatized $\mathrm{Cu}-\mathrm{K} \alpha$ radiation $(\lambda=1.54056 \AA)$ in the $2 \theta$ range of 20 to $70^{\circ}$ with a step size of $0.02^{\circ}$, time per step being $1 \mathrm{~s}$. The crystallization degree, crystallite size, and lattice constants of the crystalline phases were calculated by the Rietveld method by using Profex software (Profex 4.3.5, Open-source package for windows, Nicola Döbelin, Solothurn, Switzerland) [22].

\subsection{3. $\mathrm{pH}$ Variation Measurements}

In order to study the dissolution process of the $\mathrm{Mg}$-doped glasses, $\mathrm{pH}$ variations were measured at the end of the incubation timepoints in $\operatorname{SBF}(1,3$, and 7 days). To this end, the $\mathrm{pH}$ values of the solution were monitored by using a universal electronic $\mathrm{pH}$ meter (Hanna, Limena, Padova, Italy), which was calibrated according to internal standard operating procedures.

\subsubsection{Investigating Ion Release by ICP Analysis}

The biological performance of implanted BGs mainly depends on the release of ions from their network into the surrounding biological environment. Accordingly, the release kinetics of ions $\left(\mathrm{K}^{+}, \mathrm{Na}^{+}, \mathrm{Si}^{4+}, \mathrm{Ca}^{2+}, \mathrm{P}^{5+}\right.$, and $\left.\mathrm{Mg}^{2+}\right)$ from the $\mathrm{Mg}$-doped BGs were analyzed by inductively-coupled plasma (ICP) atomic emission spectroscopy (ICP-AES, Spectro Arcos, Kleve, Germany).

\subsection{In Vitro Cellular Responses \\ 2.3.1. Cell Culture}

The response of cells to the BG-derived scaffolds was first evaluated through different in vitro cellular assays, including cell viability, attachment, and migration, as well as osteogenic differentiation. The biological responses were measured after culturing mammalian cells in a media containing ionic dissolution products released from crushed scaffolds, named the conditioned media hereafter. In order to prepare the conditioned media, the samples were first sterilized by UV irradiation for one hour and then soaked ( $4 \mathrm{mg} / \mathrm{mL}$ ) in the RPMI-1640 medium supplemented with 10\% fetal bovine serum (FBS) and $1 \%$ penicillin/streptomycin $(\mathrm{P} / \mathrm{S})$. 


\subsubsection{Viability Assessments by MTT Assay}

The effect of ionic dissolution products released from the samples on the proliferation of osteosarcoma cells (MG-63 cell line) was evaluated by using the MTT assay. In brief, a density of $5 \times 10^{3}$ cells was seeded in 96-well plates and incubated in a $5 \% \mathrm{CO}_{2}$ humidified atmosphere at $37^{\circ} \mathrm{C}$ overnight. Thereafter, the media were replaced by conditioned media containing $4 \mathrm{mg} / \mathrm{mL}$ of crushed scaffold and incubated for a further $24 \mathrm{~h}$. Then, $10 \mu \mathrm{L}$ of the 3-(4,5-dimethylthiazol-2-yl)-2,5-diphenyl-2H-tetrazolium bromide (MTT) solution with a final concentration of $0.5 \mathrm{mg} / \mathrm{mL}$ was added to each well and incubated for another $4 \mathrm{~h}$ at $37^{\circ} \mathrm{C}$. The supernatant of the cell culture wells was gently pulled out and replaced with $100 \mu \mathrm{L}$ of dimethyl sulfoxide (DMSO) solution (Sigma-Aldrich, Saint-Louis, MO, USA) to dissolve the generated formazan crystals. After incubation in the dark for $20 \mathrm{~min}$, the optical density (OD) of dissolved formazan in each well was recorded at a wavelength of 570 by a microplate reader (Epoch, BioTek, Winooski, VT, USA).

\subsubsection{Cell Scratch Migration Assay}

The effect of the ionic dissolution product of scaffolds on the migration of human umbilical vein endothelial cells (HUVECs) was assessed using an in vitro scratch assay [23]. Briefly, $1 \times 10^{4}$ HUVECs were seeded into the 24 -well plates and cultured with the DMEMF12 medium supplemented with 5\% FBS and 1\% P/S for an overnight at $37^{\circ} \mathrm{C}$ to achieve a confluent monolayer of the cells. Then, the cell monolayer was scraped by a standard pipet tip $(200 \mu \mathrm{L})$ in a straight way to generate a scratch. After removing the debris by washing, the condition media (containing $4 \mathrm{mg} / \mathrm{mL}$ of crushed scaffold) supplemented with $1 \%$ FBS and $1 \% \mathrm{P} / \mathrm{S}$ were added to each well. The level of cell migration was measured via comparing the images captured from time 0 to defined intervals $(6,12,24,48$, and $72 \mathrm{~h}$ ) using an inverted microscope (Olympus, Japan). Finally, the data were quantified by using Image J software (NIH, Bethesda, MD, USA).

\subsubsection{In Vitro Osteogenesis by Alizarin Red S Staining}

Alizarin Red S staining assay was performed to investigate the in vitro osteogenic capability of the samples. For this purpose, osteosarcoma cells (MG-63 cell line) in a concentration of $6 \times 10^{4}$ cells were plated in T25 cell culture flasks (SPL Life Sciences, Gyeonggi-do, Korea) and incubated in a $5 \% \mathrm{CO}_{2}$ humidified atmosphere at $37{ }^{\circ} \mathrm{C}$ overnight. Then, the RPMI-1640 media were replaced with the conditioned media (containing $4 \mathrm{mg} / \mathrm{mL}$ of crushed scaffold) and followed by a further incubation for 14 days. The media were exchanged each 3-4 days once. After finishing the incubation time, all the conditioned media were aspirated, and the cells were carefully washed with PBS (three times) and fixed with a sufficient amount of $10 \%$ neutral buffered formalin (NBF) for $30 \mathrm{~min}$. Afterwards, the NBF was removed, and the cells were washed with distilled water. Finally, the cells were stained with Alizarin Red S (Sigma-Aldrich, USA) for $45 \mathrm{~min}$ at room temperature in the dark. The amount of generated calcium deposits was detected by optical microscopy observations.

\subsection{In Vivo Biocompatibility Study}

\subsubsection{Surgical Procedure}

Twenty Wistar rats at 8-10 weeks of age with an average weight of 200-250 g were purchased from Iran University of Medical Sciences, Tehran, Iran. All surgical procedures on the rats were conducted under the ethical IR-approved animal research protocol (IR.IUMS.REC.1389.2014) in accordance with the internationally accepted principles for laboratory animal use [24]. Following an acclimatization period of one week, 20 rats were randomly assigned into the control ( 4 and 12 weeks) and experimental (4 and 12 weeks) groups. The animals in control groups received no treatment while the rats in the experimental groups were treated with the $\mathrm{Mg}$-doped scaffolds. After anesthetization by $25 \mathrm{mg} / \mathrm{kg}$ of ketamine and $5 \mathrm{mg} / \mathrm{kg}$ of xylazine, a $6.0 \mathrm{~mm}$ midline incision was made on the animals' calvaria from the nasofrontal area to the external occipital protuberance along the midsagittal suture. Under constant irrigation with sterile saline, a round $6.0 \mathrm{~mm}$ diameter 
segment was detached using a trephine bur. The scaffolds, having a size of about $6 \mathrm{~mm}$ due to the volumetric shrinkage occurring upon sintering and post-sintering polishing to achieve an adequate matching with defect anatomy, were then implanted, and the skin edges were sutured by using vicryl cotton 3/0 wires (Ethicon Ltd., Edinburgh, UK), and tetracycline ointment was applied to prohibit infection (Figure 1). The animals were finally transferred into the animal household after recovery, receiving $1 \mathrm{mg} / \mathrm{kg}$ of acepromazine to relieve postoperative pain.
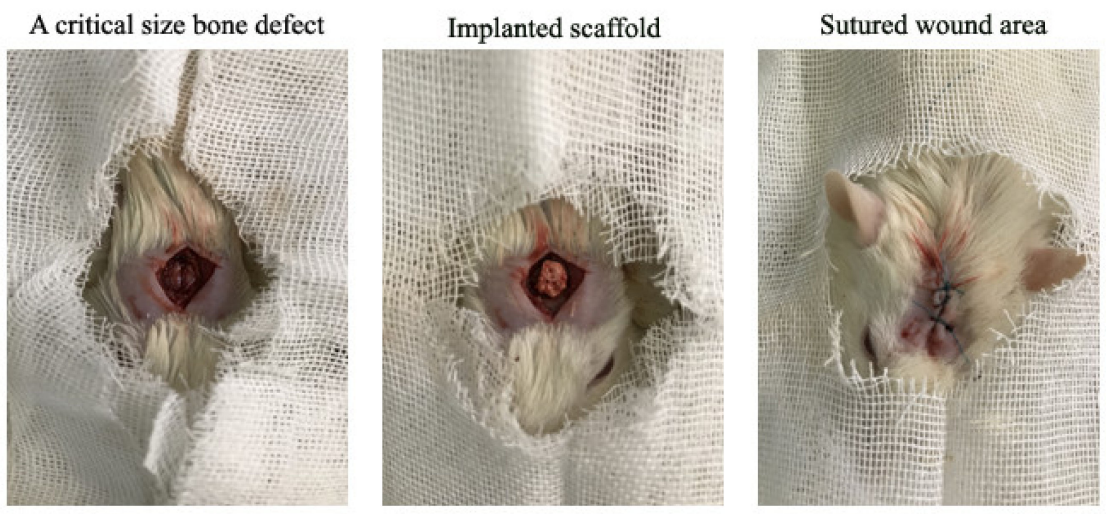

Figure 1. The surgical procedure for creating of critically-sized bone defects and subsequent implanting of the Mg-doped scaffold into rats' calvaria.

\subsubsection{Tissue Harvesting and Processing}

The animals were sacrificed at 4 and 12 weeks post-implantation, and calvaria samples were harvested and fixed in neutral buffered formalin (NBF) (10\%) for $24 \mathrm{~h}$ at room temperature. The harvested samples were then exposed to a $10 \%$ nitric acid solution (Merck, Darmstadt, Germany) for $24 \mathrm{~h}$ in order to remove the bone minerals. Afterwards, the demineralized samples were dehydrated in a series of ethanol solutions with increasing concentrations of 70,90,95, and $100 \%$, which was followed by clearing the specimens by xylene and embedding in paraffin. Lastly, serial sections of the samples were cut with a thickness of $5 \mu \mathrm{m}$ by using a microtome (Leica, Nussloch, Germany).

\subsubsection{Histology and Immunohistochemistry Evaluations}

The harvested tissue samples were stained by a commercial H\&E staining kit (SigmaAldrich, USA) to investigate the biocompatibility and the bone regeneration potential of the implanted Mg-doped BG-derived scaffolds. In addition, immunohistochemistry (IHC) was performed against osteonectin and osteocalcin proteins for 12-week implanted samples to provide detailed information about the bone regeneration capacity of the glasses. In brief, rehydration of the deparaffinized tissue segments was first performed in PBS. This was followed by incubation of the slides in 3\% hydrogen peroxide in methanol (Merck, Darmstadt, Germany) for $10 \mathrm{~min}$ in order to inactivate the endogenous peroxidase. Antigen unmasking was conducted via treating the samples in citrate buffer in an oven for $10 \mathrm{~min}$. The permeabilization of the slides was performed by their incubation in $0.3 \%$ Triton X-100 (Sigma-Aldrich, USA) for $30 \mathrm{~min}$. Then, the slides were incubated with $10 \%$ normal goat serum to block non-specific binding, followed by incubation with the primary antibodies including anti-Osteocalcin and anti-Osteonectin monoclonal antibodies (Abcam, UK) at $4{ }^{\circ} \mathrm{C}$ overnight. After thrice washing with PBS, the tissues were incubated with goat antirabbit-(IgG) antibody conjugated with Alexa-Fluor $488^{\circledR}$ for $1 \mathrm{~h}$. As the final step, the slides were stained by $4^{\prime}$,6-diamidino-2-phenylindole (DAPI) (Sigma-Aldrich, USA) to stain the nuclei and then visualized with fluorescent microscopy (Olympus, Tokyo, Japan).

\subsection{Statistical Evaluations}

The results of cell viability and migration analyses were statistically assessed by using the nonparametric Kruskal-Wallis test. Statistical significance was considered at probability 
values of $p<0.05$ (GraphPad, San Diego, CA, USA). All the experiments were performed three times and all data is presented as the mean \pm standard error.

\section{Results}

\subsection{Physico-Chemical Characteristics \\ 3.1.1. XRD Analysis}

Figure 2 shows the comparison between XRD patterns of as-quenched glass and pulverized glass-derived scaffold. The broad "bump" in Figure 2a confirms that the starting material was completely amorphous. Upon thermal treatment used for scaffold production $\left(950^{\circ} \mathrm{C}\right.$ for $3 \mathrm{~h}$ ), glass particles undergo sinter-crystallization as confirmed by the development of three crystalline phases (Figure $2 b$ ) that were identified as $\mathrm{Na}_{2} \mathrm{Ca}_{2} \mathrm{Si}_{3} \mathrm{O}_{9}$ (combeite), $\mathrm{Na}_{2} \mathrm{Ca}_{4}\left(\mathrm{PO}_{4}\right)_{2} \mathrm{SiO}_{4}$ (silicorhenanite), and $\mathrm{Ca}_{2} \mathrm{MgSi}_{2} \mathrm{O}_{7}$ (akermanite). Therefore, the resulting scaffolds are glass-ceramic materials.

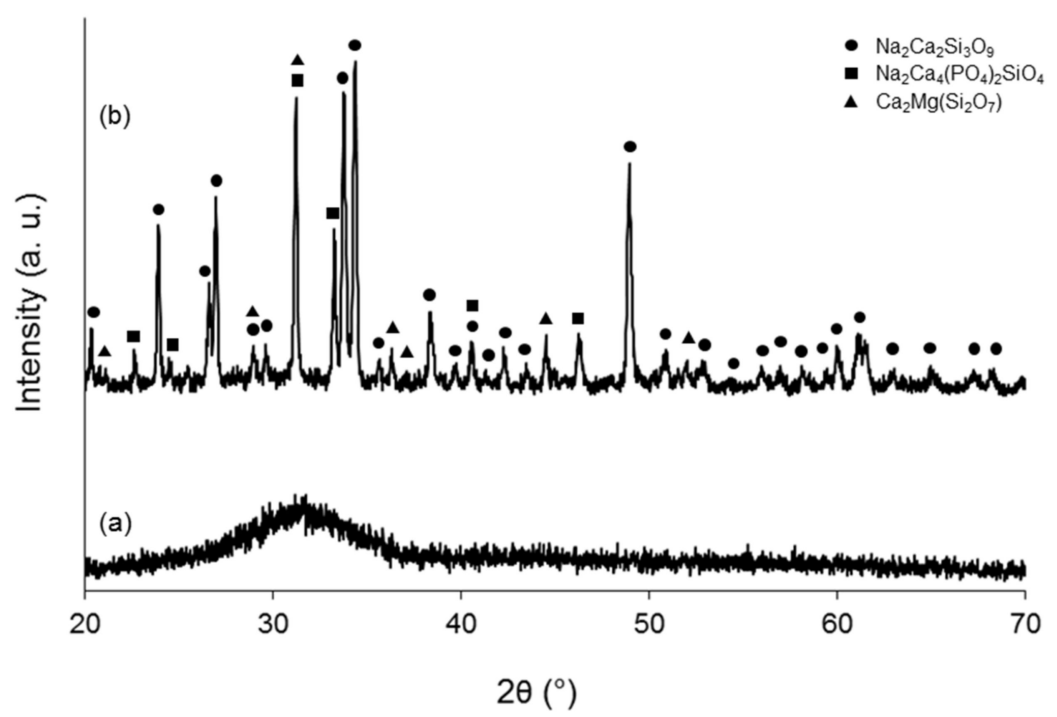

Figure 2. XRD patterns of (a) as-quenched glass powder and (b) pulverized scaffold (sintered at $950{ }^{\circ} \mathrm{C}$ for $3 \mathrm{~h}$ ) before immersion in SBF.

\subsubsection{Bioactivity Assessment}

The XRD patterns of the glass powders before and after incubation in SBF are shown in Figure 3a. Besides, the results of the calculation of crystallinity degree, crystallite size, and lattice constants are represented in Table 1 . According to the data, the crystallinity degree of glass powders before immersion in SBF is lower than $5 \%$, confirming the amorphous state of the synthesized glass. The phase transformation of glass to hydroxyapatite (HAp) (ICCD ref. code. 9-0432) was detected onto the surface of the SBF-immersed glass; the crystallinity degrees of the sample were 8,22 , and $56 \%$ after 1,3 , and 7 days of immersion, revealing that crystallinity increases over time. Moreover, according to the Rietveld refinement results (Figure $3 \mathrm{~b}$ ), the HAp was formed with an almost matched structure with a reference pattern with fitting qualities of $R_{w p}=9.21 \%, R_{\exp }=3.94 \%$, and GOF $=2.33$, which indicate a fairly acceptable refinement. The calculated crystallite sizes of the formed HAp were 12 and $63 \mathrm{~nm}$ after 3 and 7 days of immersing, confirming the growth of HAp nano-crystals onto the glass surface during the experiment. The calculated lattice constants of HAp were $(\mathrm{a}=\mathrm{b}=9.423$ and $\mathrm{c}=6.883 \AA)$ and $(\mathrm{a}=\mathrm{b}=9.419$ and $\mathrm{c}=6.880 \AA)$ after 3 and 7 days of immersion. The lattice constants were almost matched with the ICDD reference $(a=9.418$ and $c=6.884 \AA$ ). According to the data, a minor reduction of HAp lattice constants was observed in the BGs immersed in SBF for 7 days compared to their counterparts at day 3. 

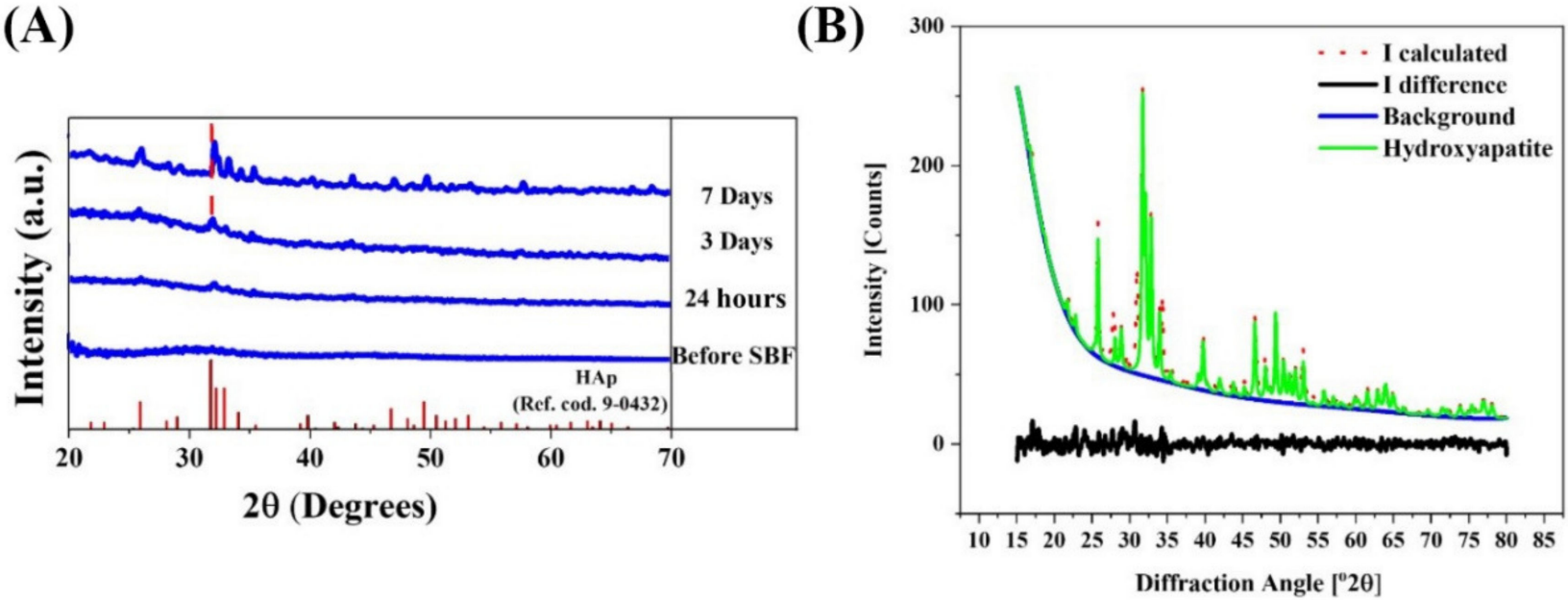

Figure 3. (A) X-ray diffraction of the Mg-doped BGs before and after immersion in SBF, which confirms the formation of a HAp layer onto the SBF-immersed samples. (B) Rietveld refinement results of the formed HAp after 7 days.

Table 1. The results of the calculation of crystallinity degree, crystallite size, and lattice constants of the formed hydroxyapatite onto the Mg-doped BGs.

\begin{tabular}{|c|c|c|c|c|c|c|c|c|c|c|}
\hline \multirow{2}{*}{$\begin{array}{c}\text { Sample } \\
\text { Days }\end{array}$} & \multicolumn{4}{|c|}{ Crystallinity(\%) } & \multicolumn{2}{|c|}{$\begin{array}{l}\text { Crystallite Size } \\
\text { (nm) }\end{array}$} & \multicolumn{2}{|c|}{$\begin{array}{l}\text { a (=b) } \\
(\AA)\end{array}$} & \multicolumn{2}{|c|}{$\begin{array}{c}\text { c } \\
\text { (̊) }\end{array}$} \\
\hline & 0 & 1 & 3 & 7 & 3 & 7 & 3 & 7 & 3 & 7 \\
\hline Glass powder & $<5$ & 8 & 22 & 56 & 12 & 63 & 9.423 & 9.419 & 6.883 & 6.880 \\
\hline ICCD reference & - & - & - & - & - & - & \multicolumn{2}{|c|}{9.418} & \multicolumn{2}{|c|}{6.884} \\
\hline
\end{tabular}

\subsubsection{SEM Observation}

Figure 4 shows the morphology and the formation of the HAp layer on the surface of the SBF-immersed Mg-doped BGs. The starting glass particles were recognized to have an irregular shape, and the growth of typical globular HAp agglomerates with cauliflower morphology was clearly detected onto the sample.
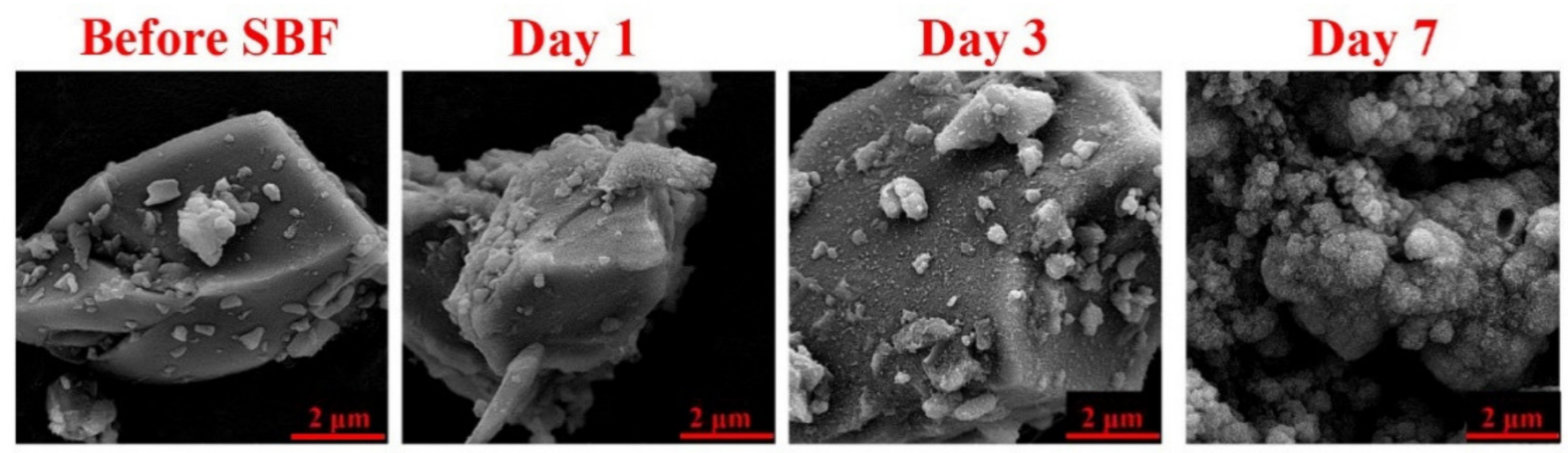

Figure 4. SEM micrographs of the Mg-doped BG particles before and after incubation in SBF (1, 3, and 7 days), which confirm the formation of hydroxyapatite layer over the immersion periods.

\subsection{4. $\mathrm{pH}$ Changes}

The $\mathrm{pH}$ changes in SBF were recorded after the incubation of the Mg-doped BGs during 7 days. As depicted in Figure 5, a sharp increase (from 7.42 to 8.33) was seen during 
the first $24 \mathrm{~h}$ of incubation, which suggests a fast release of alkaline ions in good accordance with the bioactivity mechanism postulated by Hench [25]. The increase in the $\mathrm{pH}$ continued more moderately up to day 3 , indicating the progressive formation of the HAp layer, and then a decrease was observed until day 5 . After that, the $\mathrm{pH}$ increased again from 7.99 to 8.55 during days 5 to 7 .

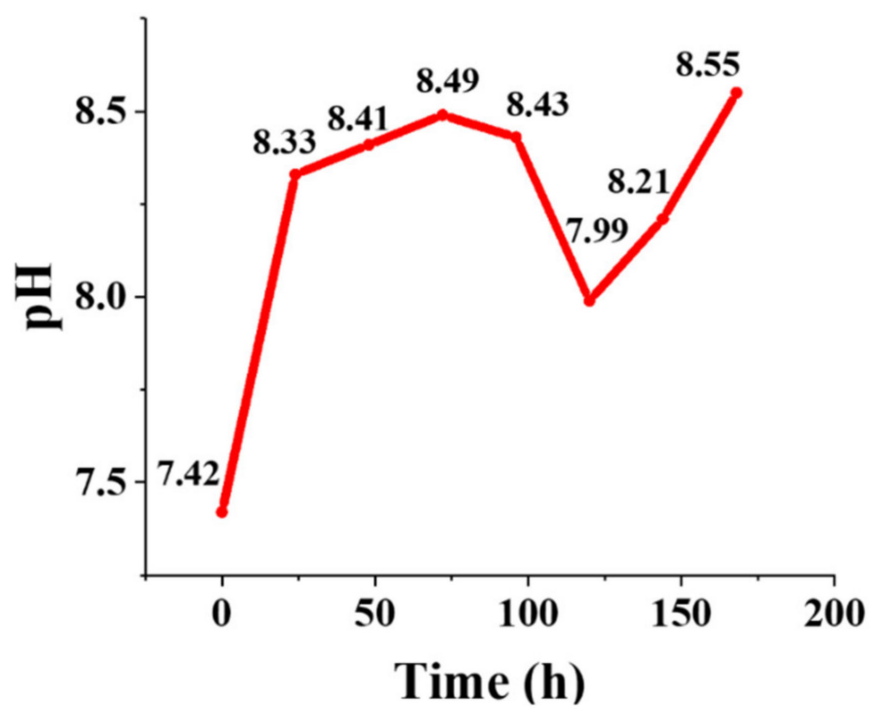

Figure 5. The graph exhibiting the $\mathrm{pH}$ variations of the glass-containing medium (SBF) during 7 days post-incubation.

\subsubsection{Ion Release}

The concentration of ionic species continuously varies during the immersion of bioactive materials in SBF as a result of the dissolution/precipitation phenomena. Figure 6 displays the ion release profile of the Mg-doped BGs over 7 days of incubation in SBF. Moreover, the calculated rates of ion release considering the slope of the curves in the different stages of immersion (linear interpolation) are represented in Table 2. According to these data, the higher release rates of $\mathrm{Na}^{+}, \mathrm{Ca}^{2+}$, and $\mathrm{Mg}^{2+}$ ions were related to the first $24 \mathrm{~h}$ post-immersion in SBF, while the higher release rates of $\mathrm{K}^{+}$and $\mathrm{Si}^{4+}$ ions were detected after $48 \mathrm{~h}$ of incubation. The increase of silicon concentration in SBF over the first 2 days corresponds to the release of soluble silica, followed by the formation of the silica gel layer. The release of silicon was then limited when the HAp layer starts to form. The rapid dissolution of the glass within the first day and the decrease of the ion release rate once HAp was formed are confirmed by the concentrations of the $\mathrm{Na}, \mathrm{Ca}, \mathrm{Mg}$, and $\mathrm{K}$ ions. The decrease of the concentration of phosphorous ions is consistent with the formation of HAp, which occurred at the expense of phosphate ion depletion in the solution. Similar ion release kinetics were observed for other melt-derived multicomponent silicate glasses during immersion in SBF [26,27].

Table 2. The calculated rates of ion release from the Mg-doped BGs.

\begin{tabular}{ccccccc}
\hline \multirow{2}{*}{ Time (h) } & \multicolumn{7}{c}{ Ion Release Rate (mg/L h) } \\
\cline { 2 - 7 } & $\mathbf{K}^{+}$ & $\mathbf{N a}^{+}$ & $\mathbf{S i}^{4+}$ & $\mathbf{C a}^{\mathbf{2 +}}$ & $\mathbf{P}^{5+}$ & $\mathbf{M g}^{\mathbf{2 +}}$ \\
\hline $0-24$ & 0 & 1.92 & 2.00 & 1 & -0.29 & 0.54 \\
\hline $24-72$ & 0.33 & 0.04 & 2.12 & 0.44 & -0.08 & 0.04 \\
\hline $72-168$ & 0.02 & 0.03 & -0.80 & 0.06 & -0.14 & 0.16 \\
\hline
\end{tabular}



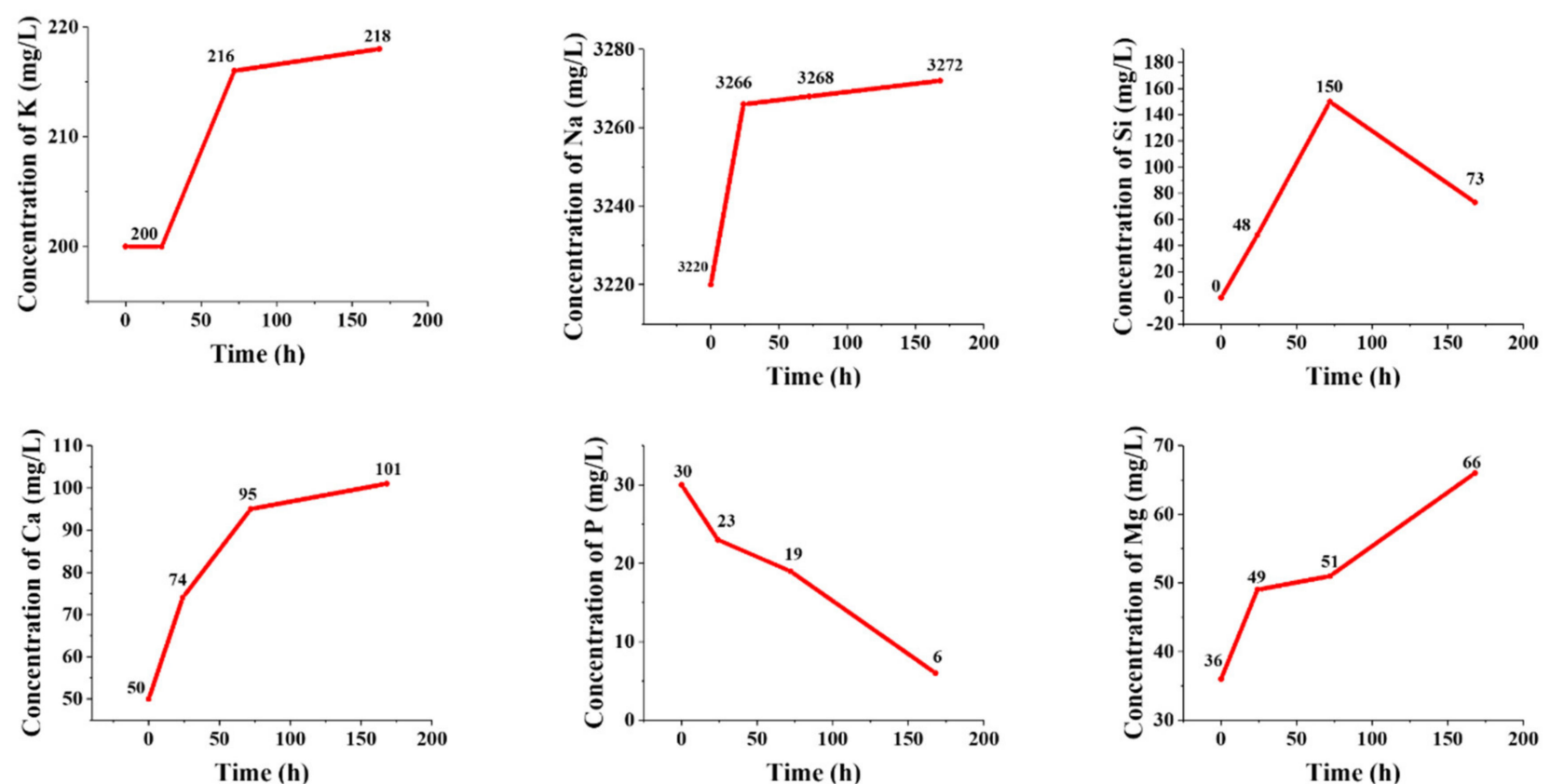

Figure 6. The release kinetic of various ions from the Mg-doped BGs, including $\mathrm{K}^{+}, \mathrm{Na}^{+}, \mathrm{Si}^{4+}, \mathrm{Ca}^{2+}$, $\mathrm{P}^{5+}$, and $\mathrm{Mg}^{2}+$, into the medium (SBF) during 7 days of incubation.

\subsection{In Vitro Cellular Responses}

\subsubsection{Cell Proliferation and In Vitro Osteogenesis}

The potential toxic effects of the Mg-doped crushed scaffolds on osteosarcoma cells (MG-63 cell line) were assessed by a standard cell viability assay (MTT assay). As displayed in Figure $7 \mathrm{~A}$, the dissolution product $(4 \mathrm{mg} / \mathrm{mL})$ of the glass-ceramic had no significant adverse effect on the cell viability after one day as compared to the untreated cells (control group). The in vitro osteogenic potential of $\mathrm{Mg}$-doped glass-ceramic was determined using an Alizarin Red staining assay. Figure 7B shows the capability of BG dissolution products of stimulating the bone nodule formation after 14 days of incubation. More extracellular calcium deposits are observed in the cells treated with the conditioned media (containing $4 \mathrm{mg} / \mathrm{mL}$ of Mg-doped glass-ceramic) in comparison to the untreated cells.

(A)

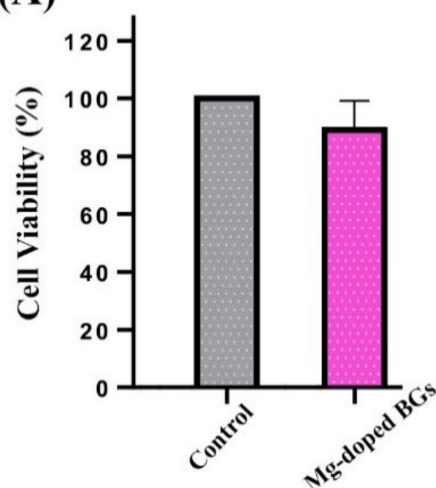

(B)

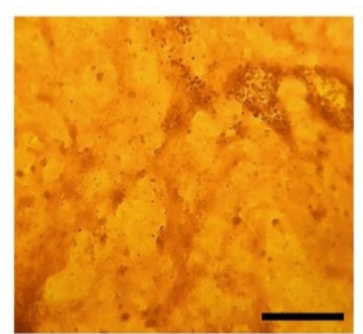

Control

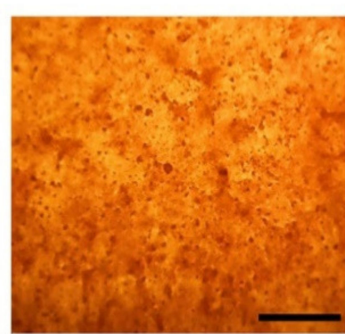

Mg-doped BGs
Figure 7. (A) The viability assessment of MG-63 cells cultured with the conditioned media containing $4 \mathrm{mg} / \mathrm{mL}$ of $\mathrm{Mg}$-doped crushed scaffolds after $24 \mathrm{~h}$ incubation. (B) Optical microscopic images of alizarin red S stained-cells for (A) untreated (control) and (B) treated with $4 \mathrm{mg} / \mathrm{mL}$ of $\mathrm{Mg}$-doped glass-ceramic at 14 days post-incubation (scale bar: $100 \mu \mathrm{m}$ ). 


\subsubsection{Cell Migration}

The effects of the crushed scaffolds on the cell movement capability were shown in Figure 8, revealing that HUVECs treated with Mg-doped glass-ceramic had a higher rate of migration in comparison with untreated counterparts (70.8. \pm 1.22 vs. $53.85 \pm 9.08$, respectively) after $24 \mathrm{~h}$ of incubation. $(p<0.05)$.

A

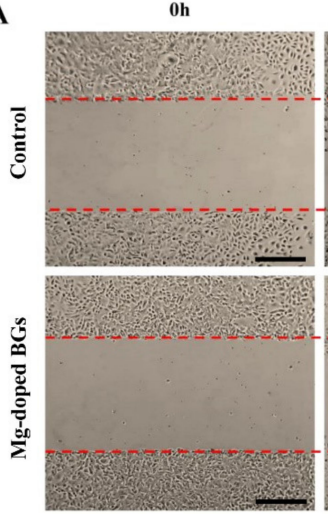

$24 \mathrm{~h}$

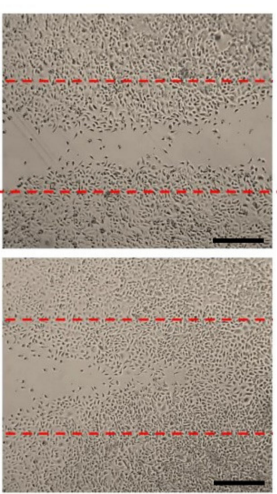

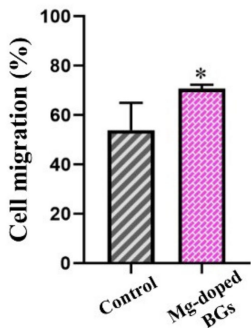

Figure 8. (A) The migration rate of HUVECs incubated with or without Mg-doped crushed scaffolds after $0 \mathrm{~h}$ and $24 \mathrm{~h}$. (B) The graph showing the migratory effects of $\mathrm{Mg}$-doped crushed scaffolds on HUVECs in comparison to the un-treated cells (control). ( $n=3$, values are represented as mean $\pm S D$, and ${ }^{*} p<0.05$ for Mg-doped BGs compared to control. Scale bars: $100 \mu \mathrm{m}$ ).

\subsection{In Vivo Biocompatibility Assessments}

The in vivo osteogenic potential of the prepared BG-derived scaffolds was initially assessed by H\&E staining of the harvested tissues at 4- and 12-weeks post-implantation. As shown in Figure 9, no significant bone regeneration is observed in the control groups (the empty surgical defect) after 4 weeks, while an irregular connective tissue is seen in the samples at 12-weeks post-surgery. Indeed, the osteogenesis occurred in the form of woven bone in the edges and centers of defects treated with the glass-derived scaffolds at 4-week post-implantation. After 12 weeks of implantation, a thicker, newly-formed bone layer is evident over the defects filled with the 3D scaffolds compared to the control groups. Based on Figure 9, it can be claimed that newly-formed, fully mature bone tissue is seen in the center of the defects filled with the Mg-doped glass-ceramic constructs.
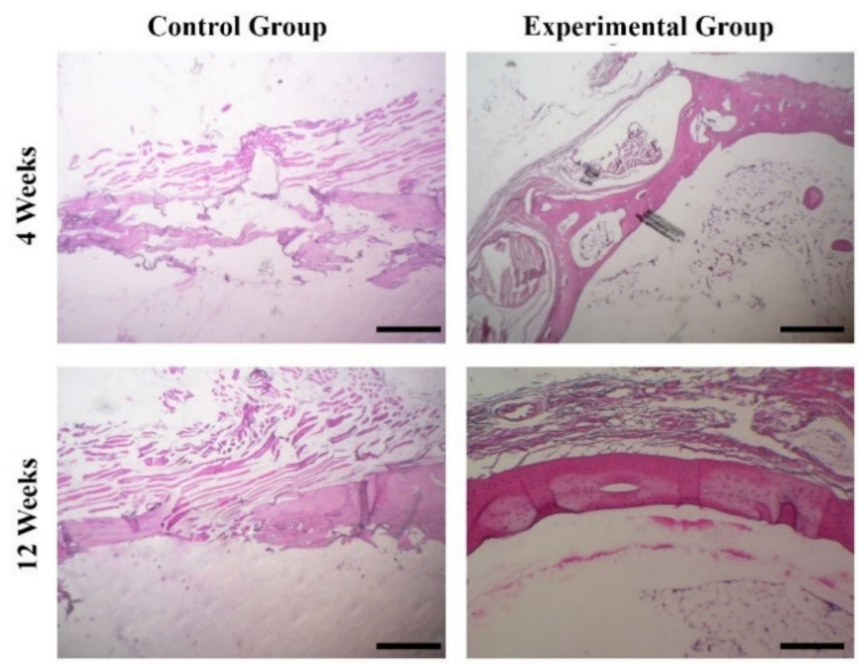

Figure 9. Histological evaluation of the Mg-doped scaffolds implanted into rat calvaria after 4 and 12 weeks. As shown, bone regeneration was clearly observed in the animals receiving the scaffolds. 
In order to provide more details on in vivo osteogenic potential of the scaffolds, the expression of osteogenic protein markers, including osteonectin and osteocalcin, was detected by the immunostaining technique after 12 weeks of implantation (see Figure 10). As compared to the control groups, the osteogenic proteins were expressed higher in the defects filled with the glass-derived scaffolds, indicating higher osteogenic differentiation and bone mineralization.

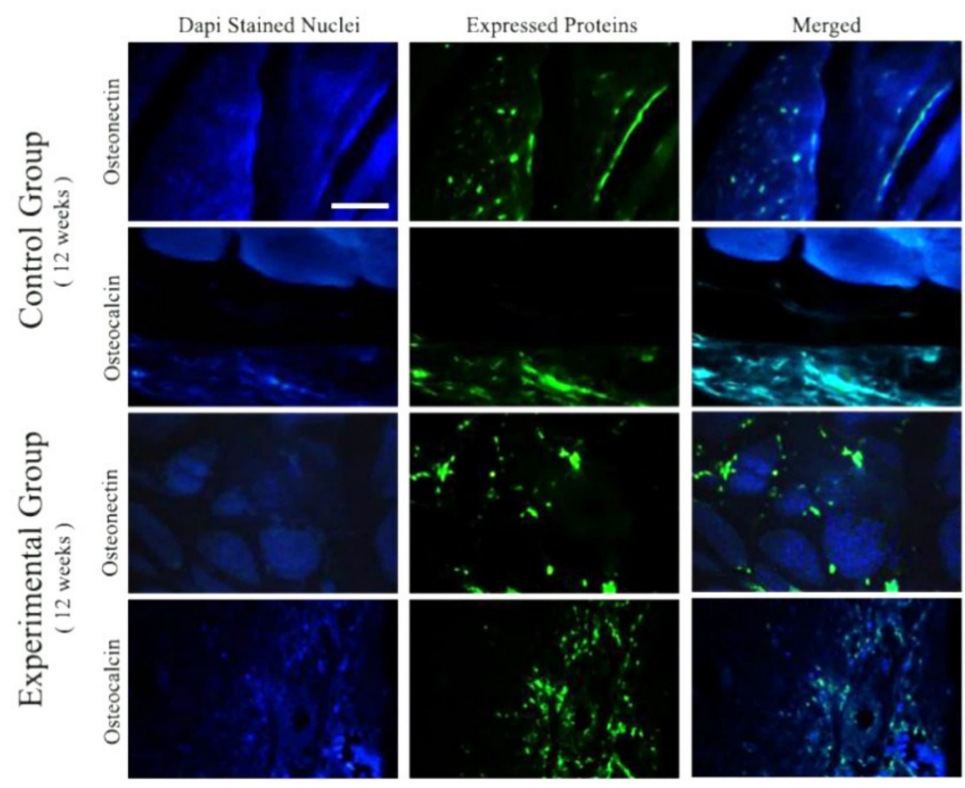

Figure 10. Immunohistochemical staining for the expression evaluation of osteocalcin and osteonectin in the samples after 12 weeks of implantation. As shown, the expression level of both osteogenesis markers is higher in the rats receiving $\mathrm{Mg}$-doped scaffolds, i.e., experimental groups. (Scale bar: $200 \mu \mathrm{m})$.

\section{Discussion}

The rules of materials science and engineering are continuously being utilized for the synthesis and preparation of biocompatible substances with the ability to accelerate the repair and regeneration of human damaged tissues. Biocompatible glasses are among the most widely used synthetic materials in both hard and soft tissue engineering strategies [28]; numerous formulations of BGs have been successfully developed by adding therapeutic cations into their basic chemical composition. In this study, we added magnesium $(\mathrm{Mg})$ to a silicate-based BG to prepare an osteogenic tissue substitute, which can be implanted into living systems. $\mathrm{Mg}$ is considered a nontoxic element for the human body at a concentration of 10-15 mM [29,30]. This element was previously demonstrated to be an effective element in promoting the proliferation and differentiation of osteoblasts through the activation of the MAPK/ERK signaling pathway [31]. Moreover, Mg can stimulate the proliferation, differentiation, and mineralization of mesenchymal stem cells (MSCs) in a dose-dependent manner through the activation of Notch1 signaling [32]. Pro-angiogenic activity of Mg is regarded as a further added value for its usability in bone tissue engineering. Indeed, $\mathrm{Mg}$ can promote angiogenesis through enhancing the production of reactive oxygen species as well as through upregulating VEGF expressions in human endothelial cells [33]. Furthermore, it has been demonstrated that this element may increase new blood vessel formation, leading to improved bone reconstruction in vivo [34,35]. However, it has been reported that exposing $\mathrm{Mg}$ to artificial body electrolytes may lead to the formation of $\mathrm{Mg}(\mathrm{OH})_{2}$, $\mathrm{MgO}_{2}$ oxide, and $\mathrm{MgCl}_{2}$. Fortunately, these by-products are excreted or integrated into the natural metabolic process [36].

Adding $\mathrm{MgO}$ as a glass modifier to the glass network could promote the formation of crystalline phases upon high-temperature thermal treatment $[37,38]$, which was actually 
confirmed by the formation of akermanite. Figure 2 shows the XRD patterns of the BGs particles and the pulverized scaffolds after sinter-crystallization at $950{ }^{\circ} \mathrm{C}$. In the basic $\mathrm{BG}$, only a broad hump in the range of $25-35^{\circ}$ is observed, confirming the amorphous nature of the glass. Sodium calcium silicate $\left(\mathrm{Na}_{2} \mathrm{Ca}_{2}\left(\mathrm{Si}_{3} \mathrm{O}_{9}\right.\right.$, combeite, ICCD ref. cod. 01-075-1686, rhombohedral), sodium calcium phosphosilicate $\left(\mathrm{Na}_{2} \mathrm{Ca}_{4}\left(\mathrm{PO}_{4}\right)_{2} \mathrm{SiO}_{4}\right.$, silicorhenanite, ICCD ref. cod. 00-033-1229), and calcium magnesium silicate $\left(\mathrm{Ca}_{2} \mathrm{MgSi}_{2} \mathrm{O}_{7}\right.$, akermanite, ICCD ref. cod. 00-079-2425, tetragonal) were detected after heat treatment at $950{ }^{\circ} \mathrm{C}$. Combeite and silicorhenanite are the same crystalline phases that develop in sintered 45S5 Bioglass ${ }^{\circledR}$ [39], which has been in clinical use for 30 years to regenerate bone; akermanite was also reported to promote new bone formation $[40,41]$.

Figure 3 shows the results of phase transformation of BGs powders to HAp during the immersion experiments in SBF. According to the results, HAp formed after 1 day of immersion, and its crystallinity increased to about $56 \%$ after 7 days of immersion. Interestingly, the lattice constants of HAp were changing during the immersion steps, which can be related to the progressive growth of HAp crystal size and the doping of some release elements to its structure [42].

Figure 4 gives detailed information on the shape and surface morphology of the synthesized glass samples. In addition, the progressive formation of a HAp layer onto the Mg-doped BGs can be detected over 7 days of the glass immersion in SBF, which is in line with previously published data [43] and ISO 23,317 (Implants for surgery) [44]. It has been reported that the incorporation of $\mathrm{Mg}$ into glasses does not suppress the formation of the surface HAp layer $[45,46]$ but may cause a delay in bioactivity. There are two main reasons behind this phenomenon, which are related to (I) the decrease of the solubility of the glass due to stronger $\mathrm{Mg}-\mathrm{O}$ chemical bonds than $\mathrm{Ca}-\mathrm{O}$ bonds and (II) the reduced rate of formation of a more stable apatite phase as a result of $\mathrm{Mg}$ leaching to SBF [47,48].

The $\mathrm{pH}$ changes of the glass-containing SBF are depicted in Figure 5. A sharp increase can be detected in the medium in the early hours after incubation. This increase is attributed to partial dissolution at the BG surfaces due to the high reactivity of this kind of biomaterial [49]. Indeed, an ion interchange occurs between $\mathrm{Na}^{+} / \mathrm{K}^{+} / \mathrm{Ca}^{2+} / \mathrm{Mg}^{2+}$ from the glass and $\mathrm{H}_{3} \mathrm{O}^{+}$from the SBF in the early stages. The process supports the formation of apatite nuclei on the silanol groups on the BG surface, which was previously well-documented [50]. It is worth mentioning that prior studies have revealed that $\mathrm{Mg}^{2+}$ ions may concentrate onto the glass surface and change the thermodynamic variables, leading to lower nucleation and crystal growth rates of HAp from its precursor, the amorphous calcium phosphate layer [46].

The release profiles of the elements, including $\mathrm{Si}, \mathrm{Ca}, \mathrm{Na}, \mathrm{P}, \mathrm{K}$, and $\mathrm{Mg}$, released from the synthesized glasses into SBF were quantified by ICP analysis and are depicted in Figure 6. As expected, a burst release for alkaline ions was observed during the first hours (up to $24 \mathrm{~h}$ ) of incubation, while the release rates decreased by day 3. In detail, the highest release rate of $\mathrm{Na}^{+}$(from 3220 to $3266 \mathrm{ppm}$ ), $\mathrm{Ca}^{2+}$ (from 50 to $74 \mathrm{ppm}$ ), and $\mathrm{Mg}^{2+}$ (from 36 to $49 \mathrm{ppm}$ ) was observed in the first $24 \mathrm{~h}$ of incubation, while the highest release rate of $\mathrm{K}^{+}$(from 200 to 216 ) and $\mathrm{Si}^{4+}$ (from 48 to $150 \mathrm{ppm}$ ) was observed over the period of 24-72 h. Furthermore, according to the data, $\mathrm{P}^{5+}$ ions were depleted from the SBF at all times of the incubation process. The highest release rate of $\mathrm{P}^{5+}$ ions were also related to the first $24 \mathrm{~h}$ of incubation (from 30 to $23 \mathrm{ppm}$ ). The decreasing rate of ion release may be due to the saturation of SBF and the formation of a surface HAp layer. Overall, the ion release trends are consistent with $\mathrm{pH}$ measurements. The highest amounts of the measured $\mathrm{Si}^{4+}, \mathrm{Ca}^{2+}, \mathrm{Na}^{+}, \mathrm{P}^{5+}, \mathrm{K}^{+}$, and $\mathrm{Mg}^{2+}$ ions released from the samples were 150, 101, $3272,30,218$, and 66 ppm from day 1 to 7 . This sustained release is a promising issue in bone tissue engineering applications, as the slow release of $\mathrm{Mg}^{2+}$ may improve the bone marrow-derived mesenchymal stem cell (BMSC) proliferation and osteoblastic activity through the PI3K/Akt/GSK3 $\beta / \beta$-catenin signal pathway in vitro [51].

BGs are generally regarded as biocompatible materials with living systems (e.g., mammalian cells). The result of MTT assay (Figure 7A) confirms the lack of adverse effects of the 
Mg-doped crushed scaffolds on osteosarcoma cells (MG-63 cell line). A slight decrease in the cell proliferation rate of the experimental group may be attributed to the potential effects of BGs in the sudden and sharp increase of the environmental $\mathrm{pH}$ [52]. This effect, i.e., the sharp increase of $\mathrm{pH}$ caused by the ion release from the BGs, was mentioned to be greatly moderate in the in vivo situation thanks to the high volume of body fluids (e.g., blood) [53]. Figure 7B illustrates the osteogenic capacity of the crushed scaffolds in vitro. As can be seen, the Mg-doped BGs could enhance the bone nodule formation, i.e., calcium deposition, in the osteoblastic cells (MG-63 cell lines) after 14 days. This finding is in agreement with previously reported studies which state that the release of therapeutic ions from BG structure into the surrounding biological environment can stimulate bone regeneration [54]. It should be pointed out that $\mathrm{Mg}^{2+}$-containing glasses were previously demonstrated to be effective in the osteogenic differentiation of mesenchymal stem cells (MSCs) [55], which make a strong concept for their utilization in bone regenerative strategies.

In addition to enhancing osteogenesis, the release of specific ions (e.g., $\mathrm{Si}^{4+}$ and $\mathrm{Ca}^{2+}$ ) from the BG structure into the biological environment can trigger other biological phenomena, including angiogenesis. In our study, the Mg-doped BGs $(4 \mathrm{mg} / \mathrm{mL})$ could enhance the migratory potential of HUVECs as compared with the control group during $24 \mathrm{~h}$ post-incubation (Figure 8). This result is in line with previously published studies, which indicate that BGs can stimulate the motility of endothelial cells (e.g., HUVECs) in vitro [8].

The Mg-doped glass-derived scaffolds were implanted into critical-sized bone defects in rats in order to investigate their biocompatibility and in vivo osteogenic capacity. It was predictable that the BGs cause no harmful side effects (e.g., chronic inflammation) in the animals' body as to the selected composition. In fact, the reactive surface of BGs is the main reason for inhibiting the formation of a fibrous capsule around glass-based implants in vivo (a hallmark of a chronic inflammatory response) and facilitating regeneration of tissue [56]. In addition, histology observations (Figure 9) confirmed that the Mg-doped BG-based scaffolds can support bone tissue engineering. These outcomes are in line with previously performed in vivo studies that introduce BGs as osteoinductive materials [57]. It has been well understood that osteocalcin (OC), a bone-specific protein, is produced by osteoblasts and represents the most abundant non-collagenous polypeptide of bone matrix [58]. More importantly, this peptide is regarded a good indicator for osteogenic maturation. Another non-collagenous protein, osteonectin (ON), plays a role in bone development and is known for its affinity for HAp and collagen [59]. Therefore, we evaluated the expression levels of these proteins in the implanted sites (Figure 10). As can be seen, higher amounts of both the osteogenic proteins were expressed in the experimental groups as compared to the control groups. It can be concluded that the implanted glass-derived scaffolds could encourage bone regeneration at the molecular levels at 12 weeks post-surgery.

\section{Conclusions}

Magnesium (Mg)-doped BGs were successfully synthesized and then used to fabricate $3 \mathrm{D}$ porous scaffolds by using the sponge replica method. The samples showed a glassy nature after the production and were able to promote HAp formation (bioactivity) postimmersion in SBF. The release of $\mathrm{Mg}^{2+}$ ions from the glasses successfully occurred over 7 days of incubation in SBF. The Mg-doped BGs caused no toxicity towards osteoblastic cells and could enhance bone nodule formation in vitro. Moreover, the glass samples could induce the migration of human endothelial cells, which might be regarded as preliminary proof of their pro-angiogenic capacity. In vivo implantation of glass-derived porous scaffolds led to enhanced bone regeneration in rats at 4- and 12-weeks post-surgery. All in all, it can be stated that Mg-doped BGs can be considered a suitable substitution biomaterial for regenerating injured bones (e.g., flat cranial bones), and the promising results reported in this study motivate further investigations. 
Author Contributions: All authors contributed to the conceptualization, literature search, methodology, investigation, writing-original draft preparation, and writing-review and editing. All authors have read and agreed to the published version of the manuscript.

Funding: This research was funded by Mashhad University of Medical Sciences (grant numbers 961592) and Iran University of Medical Sciences (grant numbers 97-01-87-32574).

Institutional Review Board Statement: All surgical procedures on the rats were conducted under the ethical IR-approved animal research protocol (IR.IUMS.REC.1389.2014) in accordance with the internationally accepted principles for laboratory animal use.

Informed Consent Statement: Not applicable.

Data Availability Statement: Data available in the study.

Conflicts of Interest: The authors declare no conflict of interest.

\section{References}

1. Kargozar, S.; Lotfibakhshaiesh, N.; Ai, J.; Mozafari, M.; Milan, P.B.; Hamzehlou, S.; Barati, M.; Baino, F.; Hill, R.G.; Joghataei, M.T. Strontium-and cobalt-substituted bioactive glasses seeded with human umbilical cord perivascular cells to promote bone regeneration via enhanced osteogenic and angiogenic activities. Acta Biomater. 2017, 58, 502-514. [CrossRef]

2. Kargozar, S.; Mozafari, M.; Hashemian, S.J.; Brouki Milan, P.; Hamzehlou, S.; Soleimani, M.; Joghataei, M.T.; Gholipourmalekabadi, M.; Korourian, A.; Mousavizadeh, K. Osteogenic potential of stem cells-seeded bioactive nanocomposite scaffolds: A comparative study between human mesenchymal stem cells derived from bone, umbilical cord Wharton's jelly, and adipose tissue. J. Biomed. Mater. Res. Part B Appl. Biomater. 2018, 106, 61-72. [CrossRef]

3. Ranjbar-Mohammadi, M.; Kargozar, S.; Bahrami, S.H.; Joghataei, M. Fabrication of curcumin-loaded gum tragacanth/poly (vinyl alcohol) nanofibers with optimized electrospinning parameters. J. Ind. Text. 2017, 46, 1170-1192. [CrossRef]

4. Johari, B.; Kadivar, M.; Lak, S.; Gholipourmalekabadi, M.; Urbanska, A.M.; Mozafari, M.; Ahmadzadehzarajabad, M.; Azarnezhad, A.; Afshari, S.; Zargan, J. Osteoblast-seeded bioglass/gelatin nanocomposite: A promising bone substitute in critical-size calvarial defect repair in rat. Int. J. Artif. Organs 2016, 39, 524-533. [CrossRef] [PubMed]

5. Baino, F.; Minguella, J.; Kirk, N.; Montealegre, M.A.; Fiaschi, C.; Korkusuz, F.; Orlygsson, G.; Chiara, V.-B. Novel full-ceramic monoblock acetabular cup with a bioactive trabecular coating: Design, fabrication and characterization. Ceram. Int. 2016, 42, 6833-6845. [CrossRef]

6. Baino, F.; Fiorilli, S.; Vitale-Brovarone, C. Bioactive glass-based materials with hierarchical porosity for medical applications: Review of recent advances. Acta Biomater. 2016, 42, 18-32. [CrossRef] [PubMed]

7. Kargozar, S.; Mozafari, M.; Hamzehlou, S.; Baino, F. Using Bioactive Glasses in the Management of Burns. Front. Bioeng. Biotechnol. 2019, 7, 62. [CrossRef]

8. Kermani, F.; Mollazadeh Beidokhti, S.; Baino, F.; Gholamzadeh-Virany, Z.; Mozafari, M.; Kargozar, S. Strontium- and cobalt-doped multicomponent mesoporous bioactive glasses (MBGS) for potential use in bone tissue engineering applications. Materials 2020, 13, 1348. [CrossRef]

9. Baino, F. How can bioactive glasses be useful in ocular surgery? J. Biomed. Mater. Res. Part A 2015, 103, 1259-1275. [CrossRef]

10. Muschler, G.F.; Nakamoto, C.; Griffith, L.G. Engineering principles of clinical cell-based tissue engineering. JBJS 2004, 86, 1541-1558. [CrossRef]

11. Dumas, J.E.; Prieto, E.M.; Zienkiewicz, K.J.; Guda, T.; Wenke, J.C.; Bible, J.; Holt, G.E.; Guelcher, S.A. Balancing the rates of new bone formation and polymer degradation enhances healing of weight-bearing allograft/polyurethane composites in rabbit femoral defects. Tissue Eng. Part A 2014, 20, 115-129. [CrossRef] [PubMed]

12. Arepalli, S.K.; Tripathi, H.; Hira, S.K.; Manna, P.P.; Pyare, R.; Singh, S. Enhanced bioactivity, biocompatibility and mechanical behavior of strontium substituted bioactive glasses. Mater. Sci. Eng. C 2016, 69, 108-116. [CrossRef] [PubMed]

13. Kargozar, S.; Mozafari, M.; Ghodrat, S.; Fiume, E.; Baino, F. Copper-containing bioactive glasses and glass-ceramics: From tissue regeneration to cancer therapeutic strategies. Mater. Sci. Eng. C 2021, 121, 111741. [CrossRef] [PubMed]

14. Janning, C.; Willbold, E.; Vogt, C.; Nellesen, J.; Meyer-Lindenberg, A.; Windhagen, H.; Thorey, F.; Witte, F. Magnesium hydroxide temporarily enhancing osteoblast activity and decreasing the osteoclast number in peri-implant bone remodelling. Acta Biomater. 2010, 6, 1861-1868. [CrossRef]

15. Kim, J.A.; Yun, H.-S.; Choi, Y.-A.; Kim, J.-E.; Choi, S.-Y.; Kwon, T.-G.; Kim, Y.K.; Kwon, T.-Y.; Bae, M.A.; Kim, N.J. Magnesium phosphate ceramics incorporating a novel indene compound promote osteoblast differentiation in vitro and bone regeneration in vivo. Biomaterials 2018, 157, 51-61. [CrossRef]

16. Watts, S.; Hill, R.; O'donnell, M.; Law, R. Influence of magnesia on the structure and properties of bioactive glasses. J. Non-Cryst. Solids 2010, 356, 517-524. [CrossRef]

17. Soulié, J.; Nedelec, J.-M.; Jallot, E. Influence of Mg doping on the early steps of physico-chemical reactivity of sol-gel derived bioactive glasses in biological medium. Phys. Chem. Chem. Phys. 2009, 11, 10473-10483. [CrossRef] 
18. Vitale-Brovarone, C.; Verné, E.; Robiglio, L.; Appendino, P.; Bassi, F.; Martinasso, G.; Muzio, G.; Canuto, R. Development of glass-ceramic scaffolds for bone tissue engineering: Characterisation, proliferation of human osteoblasts and nodule formation. Acta Biomater. 2007, 3, 199-208. [CrossRef]

19. Fiume, E.; Ciavattini, S.; Verné, E.; Baino, F. Foam Replica Method in the Manufacturing of Bioactive Glass Scaffolds: Out-of-Date Technology or Still Underexploited Potential? Materials 2021, 14, 2795. [CrossRef]

20. Baino, F.; Caddeo, S.; Novajra, G.; Vitale-Brovarone, C. Using porous bioceramic scaffolds to model healthy and osteoporotic bone. J. Eur. Ceram. Soc. 2016, 36, 2175-2182. [CrossRef]

21. Kokubo, T.; Takadama, H. How useful is SBF in predicting in vivo bone bioactivity? Biomaterials 2006, 15, 2907-2915. [CrossRef] [PubMed]

22. Döbelin, N. Interlaboratory study on the quantification of calcium phosphate phases by Rietveld refinement. Powder Diffr. 2015, 3, 231-241. [CrossRef]

23. Liang, C.-C.; Park, A.Y.; Guan, J.-L. In vitro scratch assay: A convenient and inexpensive method for analysis of cell migration in vitro. Nat. Protoc. 2007, 2, 329-333. [CrossRef]

24. Council, N.R. Guide for the Care and Use of Laboratory Animals; National Academies Press: Washington, DC, USA, 2010.

25. Hench, L.L. Bioceramics. J. Am. Ceram. Soc. 1998, 81, 1705-1728. [CrossRef]

26. Nommeots-Nomm, A.; Labbaf, S.; Devlin, A.; Todd, N.; Geng, H.; Solanki, A.K.; Tang, H.M.; Perdika, P.; Pinna, A.; Ejeian, F. Highly degradable porous melt-derived bioactive glass foam scaffolds for bone regeneration. Acta Biomater. 2017, 57, 449-461. [CrossRef]

27. Barberi, J.; Baino, F.; Fiume, E.; Orlygsson, G.; Nommeots-Nomm, A.; Massera, J.; Verné, E. Robocasting of SiO2-based bioactive glass scaffolds with porosity gradient for bone regeneration and potential load-bearing applications. Materials 2019, $12,2691$. [CrossRef] [PubMed]

28. Kargozar, S.; Singh, R.K.; Kim, H.-W.; Baino, F. "Hard" ceramics for "Soft" tissue engineering: Paradox or opportunity? Acta Biomater. 2020, 115, 1-28. [CrossRef] [PubMed]

29. Fischer, J.; Pröfrock, D.; Hort, N.; Willumeit, R.; Feyerabend, F. Improved cytotoxicity testing of magnesium materials. Mater. Sci. Eng. B 2011, 176, 830-834. [CrossRef]

30. Wang, J.; Witte, F.; Xi, T.; Zheng, Y.; Yang, K.; Yang, Y.; Zhao, D.; Meng, J.; Li, Y.; Li, W.; et al. Recommendation for modifying current cytotoxicity testing standards for biodegradable magnesium-based materials. Acta Biomater. 2015, 21, 237-249. [CrossRef] [PubMed]

31. Wang, Y.; Geng, Z.; Huang, Y.; Jia, Z.; Cui, Z.; Li, Z.; Wu, S.; Liang, Y.; Zhu, S.; Yang, X.; et al. Unraveling the osteogenesis of magnesium by the activity of osteoblasts in vitro. J. Mater. Chem. B 2018, 6, 6615-6621. [CrossRef]

32. Díaz-Tocados, J.M.; Herencia, C.; Martínez-Moreno, J.M.; Montes de Oca, A.; Rodríguez-Ortiz, M.E.; Vergara, N.; Blanco, A.; Steppan, S.; Almadén, Y.; Rodríguez, M.; et al. Magnesium Chloride promotes Osteogenesis through Notch signaling activation and expansion of Mesenchymal Stem Cells. Sci. Rep. 2017, 7, 7839. [CrossRef]

33. Park, J.; Du, P.; Jeon, J.K.; Jang, G.H.; Hwang, M.P.; Han, H.S.; Park, K.; Lee, K.H.; Lee, J.W.; Jeon, H. Magnesium corrosion triggered spontaneous generation of $\mathrm{H}_{2} \mathrm{O}_{2}$ on oxidized titanium for promoting angiogenesis. Angew. Chem. Int. Ed. 2015, 54, 14753-14757. [CrossRef]

34. Gao, P.; Fan, B.; Yu, X.; Liu, W.; Wu, J.; Shi, L.; Yang, D.; Tan, L.; Wan, P.; Hao, Y. Biofunctional magnesium coated Ti6Al4V scaffold enhances osteogenesis and angiogenesis in vitro and in vivo for orthopedic application. Bioact. Mater. 2020, 5, 680-693. [CrossRef]

35. Ma, L.; Cheng, S.; Ji, X.; Zhou, Y.; Zhang, Y.; Li, Q.; Tan, C.; Peng, F.; Zhang, Y.; Huang, W. Immobilizing magnesium ions on 3D printed porous tantalum scaffolds with polydopamine for improved vascularization and osteogenesis. Mater. Sci. Eng. C 2020, 117, 111303. [CrossRef] [PubMed]

36. Seitz, J.M.; Eifler, R.; Bach, F.W.; Maier, H. Magnesium degradation products: Effects on tissue and human metabolism. J. Biomed. Mater. Res. Part A 2014, 102, 3744-3753. [CrossRef] [PubMed]

37. Zhang, Y.; Luo, Z.; Liu, T.; Hao, X.; Li, Z.; Lu, A. MgO-doping in the $\mathrm{Li}_{2} \mathrm{O}-\mathrm{ZnO}-\mathrm{Al}_{2} \mathrm{O}_{3}-\mathrm{SiO}_{2}$ glass-ceramics for better sealing with steel. J. Non-Cryst. Solids 2014, 405, 170-175. [CrossRef]

38. Vitale-Brovarone, C.; Verné, E.; Robiglio, L.; Martinasso, G.; Canuto, R.A.; Muzio, G. Biocompatible glass-ceramic materials for bone substitution. J. Mater. Sci. Mater. Med. 2008, 19, 471-478. [CrossRef]

39. Baino, F.; Fiume, E. Quantifying the effect of particle size on the crystallization of $45 \mathrm{~S} 5$ bioactive glass. Mater. Lett. 2018, 224, 54-58. [CrossRef]

40. Wu, C.; Chang, J.; Ni, S.; Wang, J. In vitro bioactivity of akermanite ceramics. J. Biomed. Mater. Res. Part A. Off. J. Soc. Biomater. Jpn. Soc. Biomater. Aust. Soc. Biomater. Korean Soc. Biomater. 2006, 76, 73-80. [CrossRef] [PubMed]

41. Choudhary, R.; Koppala, S.; Swamiappan, S. Bioactivity studies of calcium magnesium silicate prepared from eggshell waste by sol-gel combustion synthesis. J. Asian Ceram. Soc. 2015, 3, 173-177. [CrossRef]

42. Kermani, F.; Mollazadeh, S.; Kargozar, S.; Vahdati Khakhi, J. Solution combustion synthesis (SCS) of theranostic ions doped biphasic calcium phosphates; kinetic of ions release in simulated body fluid (SBF) and reactive oxygen species (ROS) generation. Mater. Sci. Eng. C 2021, 118, 111533. [CrossRef] [PubMed]

43. Petretta, M.; Gambardella, A.; Boi, M.; Berni, M.; Cavallo, C.; Marchiori, G.; Maltarello, M.C.; Bellucci, D.; Fini, M.; Baldini, N.; et al. Composite Scaffolds for Bone Tissue Regeneration Based on PCL and Mg-Containing Bioactive Glasses. Biology 2021, 10, 398. [CrossRef] [PubMed] 
44. ISO23317. Implants for Surgery—In Vitro Evaluation for Apatite-Forming Ability of Implant Materials; International Standard ISO/FDIS, 23317; Viernier: Geneva, Switzerland, 2014.

45. Moghanian, A.; Sedghi, A.; Ghorbanoghli, A.; Salari, E. The effect of magnesium content on in vitro bioactivity, biological behavior and antibacterial activity of sol-gel derived $58 \mathrm{~S}$ bioactive glass. Ceram. Int. 2018, 44, 9422-9432. [CrossRef]

46. Souza, M.T.; Crovace, M.C.; Schröder, C.; Eckert, H.; Peitl, O.; Zanotto, E.D. Effect of magnesium ion incorporation on the thermal stability, dissolution behavior and bioactivity in Bioglass-derived glasses. J. Non-Cryst. Solids 2013, 382, 57-65. [CrossRef]

47. Ma, J.; Chen, C.; Wang, D.; Hu, J. Effect of magnesia on structure, degradability and in vitro bioactivity of CaO- $-\mathrm{MgO}_{-}-\mathrm{P}_{2} \mathrm{O}_{5}-\mathrm{SiO}_{2}$ system ceramics. Mater. Lett. 2011, 65, 130-133. [CrossRef]

48. Vallet-Regi, M.; Salinas, A.; Roman, J.; Gil, M. Effect of magnesium content on the in vitro bioactivity of CaO-MgO-SiO2-P2O5 sol-gel glasses. J. Mater. Chem. 1999, 9, 515-518. [CrossRef]

49. Mozafari, M.; Banijamali, S.; Baino, F.; Kargozar, S.; Hill, R.G. Calcium carbonate: Adored and ignored in bioactivity assessment. Acta Biomater. 2019, 91, 35-47. [CrossRef]

50. Fiume, E.; Migneco, C.; Verné, E.; Baino, F. Comparison between bioactive sol-gel and melt-derived glasses/glass-ceramics based on the multicomponent $\mathrm{SiO}_{2}-\mathrm{P}_{2} \mathrm{O}_{5}-\mathrm{CaO}-\mathrm{MgO}-\mathrm{Na}_{2} \mathrm{O}-\mathrm{K}_{2} \mathrm{O}$ system. Materials 2020, 13, 540. [CrossRef] [PubMed]

51. Liu, J.; Zeng, H.; Xiao, P.; Yang, A.; Situ, X.; Wang, Y.; Zhang, X.; Li, W.; Pan, W.; Wang, Y. Sustained Release of Magnesium Ions Mediated by a Dynamic Mechanical Hydrogel to Enhance BMSC Proliferation and Differentiation. ACS Omega 2020, 5, 24477-24486. [CrossRef] [PubMed]

52. Hohenbild, F.; Arango-Ospina, M.; Moghaddam, A.; Boccaccini, A.R.; Westhauser, F. Preconditioning of bioactive glasses before introduction to static cell culture: What is really necessary? Methods Protoc. 2020, 3, 38. [CrossRef] [PubMed]

53. Gentleman, E.; Fredholm, Y.C.; Jell, G.; Lotfibakhshaiesh, N.; O’Donnell, M.D.; Hill, R.G.; Stevens, M.M. The effects of strontiumsubstituted bioactive glasses on osteoblasts and osteoclasts in vitro. Biomaterials 2010, 31, 3949-3956. [CrossRef] [PubMed]

54. Chen, S.; Michálek, M.; Galusková, D.; Michálková, M.; Švančárek, P.; Talimian, A.; Kaňková, H.; Kraxner, J.; Zheng, K.; Liverani, L.; et al. Multi-targeted B and Co co-doped 45S5 bioactive glasses with angiogenic potential for bone regeneration. Mater. Sci. Eng. C 2020, 112, 110909. [CrossRef] [PubMed]

55. Hohenbild, F.; Arango Ospina, M.; Schmitz, S.I.; Moghaddam, A.; Boccaccini, A.R.; Westhauser, F. An In Vitro Evaluation of the Biological and Osteogenic Properties of Magnesium-Doped Bioactive Glasses for Application in Bone Tissue Engineering. Int. J. Mol. Sci. 2021, 22, 12703. [CrossRef] [PubMed]

56. Joy-anne, N.O.; Su, Y.; Lu, X.; Kuo, P.-H.; Du, J.; Zhu, D. Bioactive glass coatings on metallic implants for biomedical applications. Bioact. Mater. 2019, 4, 261-270.

57. Schmitz, S.; Widholz, B.; Essers, C.; Becker, M.; Tulyaganov, D.; Moghaddam, A.; de Juan, I.G.; Westhauser, F. Superior biocompatibility and comparable osteoinductive properties: Sodium-reduced fluoride-containing bioactive glass belonging to the $\mathrm{CaO}-\mathrm{MgO}-\mathrm{SiO}_{2}$ system as a promising alternative to $45 \mathrm{~S} 5$ bioactive glass. Bioact. Mater. 2020, 5, 55-65. [CrossRef]

58. Burr, D.B.; Bellido, T.; White, K.E. Bone structure and function. In Rheumatology, 6th ed.; Hochberg, M.C., Silman, A.J., Smolen, J.S., Weinblatt, M.E., Weisman, M.H., Eds.; Mosby: Philadelphia, PA, USA, 2015; Chapter 6; pp. 42-55.

59. Price, J. Bone Biomarkers. In Diagnosis and Management of Lameness in the Horse, 2nd ed.; Ross, M.W., Dyson, S.J., Eds.; W.B. Saunders: Saint Louis, MO, USA, 2011; Chapter 101; pp. 947-952. 